300

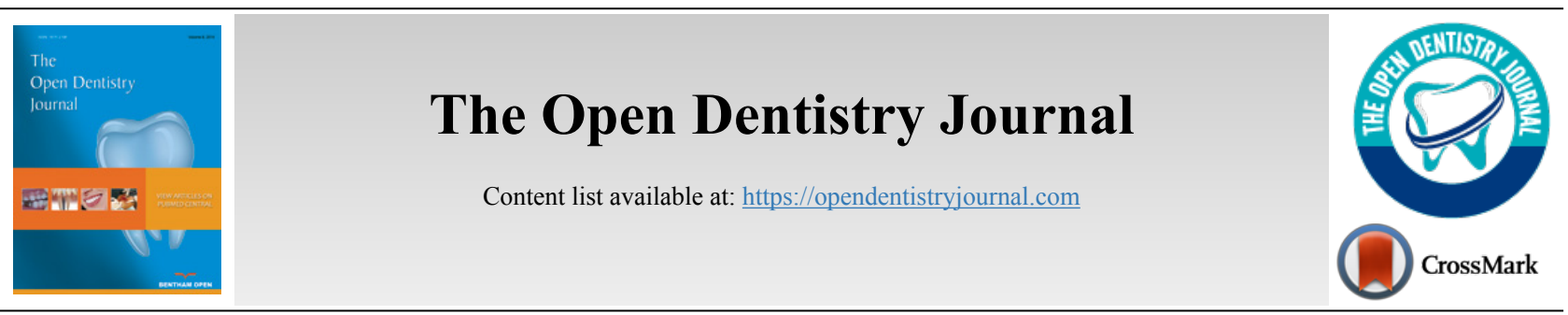

REVIEW ARTICLE

\title{
The Novel Coronavirus in Pediatric and Geriatric Population- What We Know
}

\author{
Amit Reche ${ }^{1, *}$, Anjali Nandanwar ${ }^{2}$, Aniket Hedaoo ${ }^{2}$, Kumar G. Chhbra ${ }^{1}$, Punit Fulzele ${ }^{3}$ and Gargi Nimbulkar ${ }^{1}$

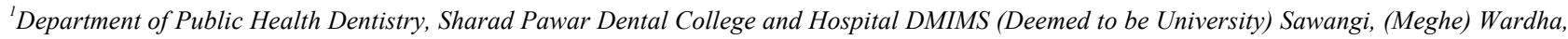 \\ 442001 Maharashtra, India \\ ${ }^{2}$ Sharad Pawar Dental College and Hospital DMIMS (Deemed to be University) Sawangi, (Meghe) Wardha, 442001 Maharashtra, India \\ ${ }^{3}$ Department of Pedodontics \& Preventive Dentistry, Sharad Pawar Dental College and Hospital DMIMS (Deemed to be University) Sawangi, \\ (Meghe) Wardha, 442001 Maharashtra, India.
}

\begin{abstract}
:
Severe acute respiratory syndrome coronavirus 2 (SARS-CoV-2)is a virus responsible for the coronavirus infection that is currently causing a severe outbreak of the disease in the world, infecting and killing thousands to lacs of people. The pediatric and geriatric population is no exception to this. Children and older adults have less immunity, which makes them more susceptible to infection than other populations. But still the number of cases of Children where less as compared to adults and those having underlying pulmonary pathology or immunocompromising conditions are more vulnerable to infection. Some studies have shown that this virus causes more death in the older age population as compared to adults or children. Patients having any systemic conditions like diabetes, raised blood pressure, heart diseases, lung diseases and chronic renal diseases were more vulnerable to this infection. In this article, we will outline the epidemiology, symptoms, diagnosis, and treatment modalities of the novel coronavirus-2019(COVID 19) infection in humans, with more focusing on infection in children as well as in older adults.
\end{abstract}

Keywords: - COVID 19, Pediatric, Geriatric, Infection, Respiratory diseases, Children.

\begin{tabular}{l|l|l|l} 
Article History & Received: July 31, 2020 & Revised: December 11, 2020 & Accepted: December 29, 2020
\end{tabular}

\section{INTRODUCTION}

Coronaviruses belonging to the family Coronaviridae [1]. They also infect various animals and may cause cardiovascular, neurologic, and respiratory diseases $[2,3]$. In humans, it mostly causes respiratory diseases such as Bronchitis, Pneumonia, Acute respiratory disease syndrome, multi-organ failure and at the last death and gastrointestinal symptoms also seen. Betacoronavirus is responsible for the infection in mammals [4]. This coronavirus was originally derived from bat, camels, cat, and dromedary [1]. The first occurrence of coronavirus in a human was in 2002 in China and was responsible for a severe acute respiratory disease that was spread from diseased cats or bats to humans [5, 6]. In 2012, another Novel coronavirus was found in Saudi Arabia, which causes Middle East respiratory disease in humans and this virus was transmitted by Dromentary, the camel. In 2019, Novel coronaviruses belonging to the Betacorona virus were the reason for many deaths in Wuhan, China. Bats were responsible for this disease. The local seafood and animal market were spotted as a source of infection [1]. The droplets of disease people spread the

\footnotetext{
* Address correspondence to this author at the Department of Public Health Dentistry, Sharad Pawar Dental College and Hospital DMIMS (Deemed to be University) Sawangi, (Meghe) Wardha, 442001 Maharashtra, India; Tel: 9096469080; E-mail: dramitreche@gmail.com
}

infection in the population and it spreads in various cities of China [7]. Internationally corona has been spread and is scared to cause a world pandemic. The term COVID -19 was given to symptomatic disease caused by SARS-CoV-2 [1].

\section{EPIDEMIOLOGY}

Children below 3 years old and those who are suffering from heart disease were more susceptible for Covid 19 human coronaviruses(HCoVs) were isolated from $4 \%-6 \%$ of children who were hospitalized for respiratory disease [1]. Children who are suspected of Covid-19 were more likely to suffer from underlying chronic respiratory diseases [8]. Seasonal patterns were noticed in the North and South hemispheres. From December to May, more patients were suffering from HCoVs infection in the North hemisphere. In the South hemisphere, infection at the peak was between March and November [9, 10]. SARS-CoV-2 is a unique group Betacoronavirus was first noticed in China that ailment lower respiratory tract problems in 2002 and then followed by Hongkong and many other countries. A total of 29 countries were infected, caused by more than 8000 infections and 774 deaths all over the world [1]. Middle East respiratory syndrome coronavirus (MERS$\mathrm{CoV}$ ) is also a unique group of Betacoronavirus found in Saudi Arabia which was spread from person to person and causes 
lower respiratory infection in $2012[11,12]$ Number of Pneumonia cases were noticed in the City of Wuhan, China which was diagnosed as Severe Acute Respiratory Syndromes [13]. On epidemiologic investigation, the Chinese government declared that the origin of the virus was from seafood shop Huanan in Wuhan, and it was just hypothesized that Intermediate host Bat was spreading this disease because of similarity to bat coronavirus [14]. This disease was spread by person-to-person contact and turned into Pandemic disease. On March 11, 2020, the World Health Organization (WHO) announced coronavirus disease as pandemic \& by March 23,2020 a total of 3,62,019 confirmed cases were addressed from 168 nations with 15,488 fatalities which means a total $4.3 \%$ fatality rate [15]. The Centers for Disease Control and Prevention (CDC) addressed patients above 65 years of age were $31 \%$ of COVID 19 infections from which $45 \%$ of patients were hospitalized and only $20 \%$ were survived in the United States [16]. This concludes that older age group people were more prone to Coronavirus disease as compared to general people.

\section{SYMPTOMS}

The Chinese Centers for Disease Control and Prevention noticed that only $2 \%$ of the total disease population were patients less than 19 years. This shows that children are less prone to corona disease [17].

There are some cases of children infected by COVID 19:

[a] Case of 31 January 2020 at Zhejiang, 20 children were infected with COVID 19 and few symptoms were observed that are Low to moderate fever, Cough, Headache, Dysentery, and dyspnea [18].

[b] Case of 19 January 2020 and 7 February 2020 at Shenzhen, it has been noticed that a total of 34 children more than 20 were having a common respiratory infection and 5 were asymptomatic and remaining were mild symptomatic. Fever and cough were the most common symptoms [19].

[c] February 2020 - 9 infants from provinces in China were reported; only 4 of them have a fever. Many children were recovered in two weeks and one of them was asymptomatic [20].

From the above series, it has been concluded that children were less prone to this infection compared to adults and the older age population.

Fever, cough, Dyspnea, myalgias, and fatigue were common symptoms of COVID infection in the population [21, 22]. Whereas Shortness of breath, cough, and Fever was mostly seen in older age diseased people. Many of the older patients were known to systematically diseases like Diabetes, Hypertension, heart diseases, respiratory disease, and chronic kidney disease [23] and because of all this reason,the mortality rate of older adults is more as compared to the general population.

\section{DIAGNOSIS}

The diagnosis of a positive case of Covid-19 can be made with the help of signs, symptoms and history of the patient. On this basis, they can be divided into suspected cases and confirmed cases.

\subsection{The Suspected Cases can be Diagnosed as Follows}

The suspected cause is the one in which at least one out of the four standards in the epidemiological history and at least two out of the four standards in clinical history are met [24].

\subsubsection{Epidemiological History}

[1] Kids / elderly people having a travel history from a corona hotspot region.

[2] Kids / elderly people who came in contact with a person having a fever or cough.

[3] Kids / elderly people who are relatives of Covid-19 positive tested patients.

[4] Babies born to Covid-19 positive females.

\subsubsection{Clinical Manifestations}

[1] The most primary symptom is fever, cough, and fatigue.

[2] Positive chest imaging findings.

[3] Reduced lymphocyte and leucocyte count in the initial phase of the infection.

[4] Any additional microorganism not being encountered that could justify the symptoms.

\subsection{Diagnosis of the Confirmed Cases can be Made as Follows}

Any person having positive epidemiological and clinical history who meets at least one of the below-mentioned standards is diagnosed as a positive patient [25].

[1] Nasopharyngeal tract samples or hematological specimens assessed conclusively for Covid-19 [25].

[2] Gene sequencing of hematological samples or nasopharyngeal tract samples is extremely correlative for the COVID -19 [25].

The prime route of entrance for the Covid-19 virus is by way of the upper airway and subsequently, it reaches the lower airway [26]. Real-time polymerase chain reaction (RT-PCR) is principally utilized for the identification of coronaviruses in man from upper or lower respiratory tract samples [27]. For Covid-19, elevated counts are identified from the lower airway secretions in comparison to the upper airway secretions [7]. Hence, the repetition of testing of samples is recommended in suspected patients with a negative result at first [1]. Faecal samples are not used routinely for RT-PCRs [28]. Kids could have increased upper airway involvement compared to lower airway [29].

\subsubsection{Differential Diagnosis}

The coinfection of SARS-CoV-2 with additional bacteria and/or viruses such as bacterial pneumonia, adenovirus, common flu, influenza virus, the respiratory syncytial virus 
should be reviewed before arriving at a diagnosis [25].

\section{PREVENTION}

The manner of spreading of coronavirus infection is droplet mediated. Also, the virus can persist on the surface of the skin and inanimate objects actively for many hours to somedays. Thus, washing hands regularly with hand wash or soap and/or disinfecting hands with an alcohol-based sanitizer is strongly advocated, especially after exposure to any patient or touching any surface which would probably possess the virus. One should avoid touching his/her face, particularly the eyes, mouth, and nose, because it is a potential route of ingressing the virus [30]. Social distancing is recommended in which people should keep a distance of at least 6 feet from each other to prevent the spread of viral infection. Healthcare workers should use personal protective equipment (PPE) compulsorily [31]. Persons who came in touch with a potentially infected person should be investigated and isolated for a minimum of two weeks [30].

\subsection{To Control Potential Sources of Infection}

A Covid-19 positive patient is the primary source of infection. The infected kids/ older adults should be isolated and treated at designated hospitals under the supervision of doctors. The probability of contact with other people can be decreased by providing single rooms. The room ventilation required disinfection and cleaning for the articles used by children should be judiciously done. The proper disposal of masks after use while taking care of the patient is also important [24].

\subsection{Stopping Communication Means}

To halt the droplet spread, the mouth and nose should be kept covered with the help of a mask or handkerchief while a person is coughing or sneezing. Hands should be washed often. Touching areas of the face should be avoided. Visiting overcrowded and congested public places should be avoided. Toys and things frequently used should be disinfected routinely. Children as well as elders should be monitored regularly for any symptoms, especially with a known case of exposure with affected family members or relatives. If in doubt, they should be screened at a designated hospital.Infants delivered by infected women should undergo a pathogen test and keep isolated [32]. More than 10 crores of elderly adults are comorbid in India, which increases their risk of infection [33]. Patients with more than one co-morbidities such as diabetes accompanied by tuberculosis lung or extrapulmonary tuberculosis should be kept under observation and their sugar levels should be monitored [34].

\subsection{Increasing the Body's Defense Power}

A balanced diet, regular exercise and boosting immunity are the potent steps to prevent getting infected, in addition to preserving psychological health and rational stability [24].

\subsection{Treatment}

It is difficult to ascertain routine clinical traits in children and old aged adults with serious diseases. Treatments advised are based on observations, rather than proof from clinical trials
[35]. The management is concentrated on supportive therapy. Even if at present, there is no confirmed therapy, numerous medicines are reviewed to check the efficacy to counter the virus [36].

\subsection{General Treatment}

The common treatment approaches include supportive treatment and bed rest, making sure adequate calorie and water intake is maintained, sustaining ionic equilibrium; keeping track of vitals and blood oxygen saturation levels; maintaining airway clear, doing blood as well as other tests routinely and examination of chest imaging periodically when necessary [24].

\subsection{Symptomatic Treatment}

High fever (body temperature exceeding $38.5^{\circ} \mathrm{C}$ ) should be actively curbed with the help of physical cooling and/or antipyretic drugs. Sedatives can be useful in keeping children stay quiet [24]. Chloroquine, a Food and Drug Administration (FDA)-approved drug for malarial, has shown effectiveness againstCovid-19 in-laboratory trials. The mechanism of action is by elevating the $\mathrm{pH}$ and by inhibiting the glycosylation [37]. Another drug with favorable outcomes is Remdesivir, which hampers viral replication by terminating the viral ribonucleic acid (RNA). It is a non-FDA approved medicine under research, which is helpful to counter SARS-CoV-2 in laboratory trials [38]. There is no advantage of taking the influenza vaccine for precaution against Covid-19 infection. It is advised to obtain the influenza vaccine in children over 6 months of age to prevent influenza and unneeded assessment for COVID-19 [39].

\section{CONCLUSION}

Kids of all ages seemed vulnerable to COVID-19with no notable gender variation. Even though clinical manifestations of children were less serious than those of elderly people, infants speculiarly were susceptible to infection [29]. Juvenile age, associated comorbidities, and immune deficient states are correlated with serious consequences with the coronavirus infection in the pediatric age group [40], infants and preschoolaged kids were expected to have more serious clinical manifestations than older children. Also, there is support for the presence of the virus in the stools for many days after its identification, causing worry about fecal to the oral transfer of the virus, especially for kids who don't have proper control of bladder and bowel functions [41]. On the contrary, elderly adults encounter many of the long-standing diseases and disorders as well as improper immune function; it is believed thatthe coronavirus shall have an impact on this population out of proportion.Concluding, many contagious diseases influence the pediatric and the geriatric population distinctively from the adults, and interpreting those variations can provide major perception into the viral progression of the disease and the development of remedies.

\section{CONSENT FOR PUBLICATION}

Not applicable. 


\section{FUNDING}

None.

\section{CONFLICT OF INTEREST}

The authors declare no conflict of interest, financial or otherwise.

\section{ACKNOWLEDGEMENTS}

Declared none.

\section{REFERENCES}

[1] Zimmermann P, Curtis N. Coronavirus infections in children including COVID-19: An overview of the epidemiology, clinical features, diagnosis, treatment and prevention options in children. Pedi Infect Disease J 39(5): 355 .

[2] Amer HM. Bovine-like coronaviruses in domestic and wild ruminants. Anim Health Res Rev 2018; 19(2): 113-24. [http://dx.doi.org/10.1017/S1466252318000117] [PMID: 30683171]

[3] Saif LJ. Animal coronaviruses: What can they teach us about the severe acute respiratory syndrome? Rev Sci Tech 2004; 23(2): 643-60. [http://dx.doi.org/10.20506/rst.23.2.1513] [PMID: 15702725]

[4] da Silva Filho LV, Zerbinati RM, Tateno AF, et al. The differential clinical impact of human coronavirus species in children with cystic fibrosis. J Infect Dis 2012; 206(3): 384-8.

[http://dx.doi.org/10.1093/infdis/jis274] [PMID: 22459737]

[5] Shi Z, Hu Z. A review of studies on animal reservoirs of the SARS coronavirus. Virus Res 2008; 133(1): 74-87. [http://dx.doi.org/10.1016/j.virusres.2007.03.012] [PMID: 17451830]

[6] Luk HKH, Li X, Fung J, Lau SKP, Woo PCY. Molecular epidemiology, evolution and phylogeny of SARS coronavirus. Infect Genet Evol 2019; 71: 21-30.

[http://dx.doi.org/10.1016/j.meegid.2019.03.001] [PMID: 30844511]

[7] Chan JF, Yuan S, Kok KH, et al. A familial cluster of pneumonia associated with the 2019 novel coronavirus indicating person-toperson transmission: A study of a family cluster. Lancet 2020; 395(10223): $514-23$

[http://dx.doi.org/10.1016/S0140-6736(20)30154-9] [PMID: 31986261]

[8] Kuypers J, Martin ET, Heugel J, Wright N, Morrow R, Englund JA. Clinical disease in children associated with newly described coronavirus subtypes. Pediatrics 2007; 119(1): e70-6. [http://dx.doi.org/10.1542/peds.2006-1406] [PMID: 17130280]

[9] Cabeça TK, Granato C, Bellei N. Epidemiological and clinical features of human coronavirus infections among different subsets of patients. Influenza Other Respir Viruses 2013; 7(6): 1040-7. [http://dx.doi.org/10.1111/irv.12101] [PMID: 23462106]

[10] Gaunt ER, Hardie A, Claas EC, Simmonds P, Templeton KE. Epidemiology and clinical presentations of the four human coronaviruses 229E, HKU1, NL63, and OC43 detected over 3 years using a novel multiplex real-time PCR method. J Clin Microbiol 2010; 48(8): 2940-7.

[http://dx.doi.org/10.1128/JCM.00636-10] [PMID: 20554810]

[11] de Groot RJ, Baker SC, Baric RS, et al. Middle East respiratory syndrome coronavirus (MERS-CoV): Announcement of the Coronavirus Study Group. J Virol 2013; 87(14): 7790-2. [http://dx.doi.org/10.1128/JVI.01244-13] [PMID: 23678167]

[12] Munster VJ, Koopmans M, van Doremalen N, van Riel D, de Wit E. A novel coronavirus emerging in China - key questions for impact assessment. N Engl J Med 2020; 382(8): 692-4. [http://dx.doi.org/10.1056/NEJMp2000929] [PMID: 31978293]

[13] COVID-19 in Older Adults - Zainab Shahid. BS1,2, Ricci Kalayanamitra, BS3,4, Brendan McClafferty, BS, Douglas Kepko, BS, DevyaniRamgobin, BS, Ravi Patel, DO, ChanderShekher Aggarwal, MBBS, Rama Rao Vunnam, MD, NitasaSahu, MD, Dhirisha Bhatt, MD, Kirk Jones, PharmD8, ReshmaGolamari, MD, Rohit Jain, MD.

[14] Andersen KG, Rambaut A, Lipkin WI, Holmes EC, Garry RF. The proximal origin of SARS-CoV-2. Nat Med 2020; 26(4): 450-2. [http://dx.doi.org/10.1038/s41591-020-0820-9] [PMID: 32284615]

[15] Coronavirus COVID-19 Global Cases by the Center for Systems Science and Engineering (CSSE) at Johns Hopkins University. https://coronavirus.jhu.edu/map.html

[16] Severe Outcomes Among Patients with Coronavirus Disease 2019
(COVID-19) - United Stated February 12 - March 162020. https://www.cdc.gov/mmwr/volumes/69/wr/mm6912e2.htm

[17] Wu Z, McGoogan JM. Characteristics of and important lessons from the coronavirus disease 2019 (COVID-19) outbreak in China: Summary of a report of 72314 cases from the Chinese center for disease control and prevention. JAMA 2020. [Epub ahead of print] [http://dx.doi.org/10.1001/jama.2020.2648]

[18] Chen ZM, Fu JF, Shu Q, et al. Diagnosis and treatment recommendations for pediatric respiratory infection caused by the 2019 novel coronavirus. World J Pediatr 2020; 16(3): 240-6. [Epub ahead of print]

[http://dx.doi.org/10.1007/s12519-020-00345-5] [PMID: 32026148]

[19] Wang XF, Yuan J, Zheng YJ, et al. Clinical and epidemiological characteristics of 34 children with 2019 novel coronavirus infection in Shenzhen. ZhonghuaErKeZaZhi 2020; 58E008.

[20] Wei M, Yuan J, Liu Y, Fu T, Yu X, Zhang ZJ. Novel coronavirus infection in hospitalized infants under 1 year of age in China. JAMA 2020; 323(13): 1313-4. [Epub ahead of print]

[http://dx.doi.org/10.1001/jama.2020.2131] [PMID: 32058570]

[21] Huang C, Wang Y, Li X, et al. Clinical features of patients infected with 2019 novel coronavirus in Wuhan, China. Lancet 2020; 395(10223): 497-506.

[http://dx.doi.org/10.1016/S0140-6736(20)30183-5]

[PMID: 31986264]

[22] Zhu W, Xie K, Lu H, Xu L, Zhou S, Fang S. Initial clinical features of suspected coronavirus disease 2019 in two emergency departments outside of Hubei, China. J Med Virol 2020; 92(9): 1525-32. [http://dx.doi.org/10.1002/jmv.25763] [PMID: 32167181]

[23] Arentz M, Yim E, Klaff L, et al. Characteristics and Outcomes of 21 Critically Ill Patients With COVID-19 in Washington State. JAMA 2020; 323(16): 1612-4.

[http://dx.doi.org/10.1001/jama.2020.4326] [PMID: 32191259]

[24] Shen K, Yang Y, Wang T, et al. Diagnosis, treatment, and prevention of 2019 novel coronavirus infection in children: Experts' consensus statement. World J of Ped 2020; 16(13): 223-31

[http://dx.doi.org/10.1007/s12519-020-00343-7]

[25] National Health Commission of People's Republic of China. Diagnosis and treatment of pneumonia caused by novel coronavirus (trial version 4) https://www.nhc.gov.cn/xcs/zhengcwj/202001/42945 63ed35b43209b31739bd0785e67/fles/7a930911

1267475a99d4306962c8bf78.pdf

[26] Xu Z, Shi L, Wang Y, et al. Pathological findings of COVID-19 associated with acute respiratory distress syndrome. Lancet Respir Med 2020; 8(4): 420-2.

[http://dx.doi.org/10.1016/S2213-2600(20)30076-X]

[27] Vabret A, Mourez T, Gouarin S, Petitjean J, Freymuth F. An outbreak of coronavirus OC43 respiratory infection in Normandy, France. Clin Infect Dis 2003; 36(8): 985-9.

[http://dx.doi.org/10.1086/374222] [PMID: 12684910]

[28] Jevšnik M, Steyer A, Zrim T, et al. Detection of human coronaviruses in simultaneously collected stool samples and nasopharyngeal swabs from hospitalized children with acute gastroenteritis. Virol J 2013; 10: 46.

[http://dx.doi.org/10.1186/1743-422X-10-46] [PMID: 23379823]

[29] Dong Y, Mo X, Hu Y, et al. Epidemiology of COVID-19 among children in China. Pediatrics 2020; 145(6): e20200702. [http://dx.doi.org/10.1542/peds.2020-0702] [PMID: 32179660]

[30] Coronavirus disease 209 in geriatrics and long term care: the ABCDs of Covid -19Heather d'Adamo. Joseph G Ouslander: Thomas Yoshikawa 2017

[31] Kampf G, Todt D, Pfaender S, Steinmann E. Persistence of coronaviruses on inanimate surfaces and their inactivation with biocidal agents. J Hosp Infect 2020; 104(3): 246-51. [http://dx.doi.org/10.1016/j.jhin.2020.01.022] [PMID: 32035997]

[32] The US Centers for Disease Control and Prevention. Interim Guidance for Preventing 2019 Novel Coronavirus (2019-nCoV) fromSpreading to Others in Homes and Communities 2019.https://www.cdc.gov/ coronavirus/2019-ncov/guidance-prevent-spread-chine se.html Access 20 Jan 202044].COVID-19 infection in children

[33] Kumar S, Jain S, Wanjari A, Mandal S. Development and validation of a modified frailty risk index as a predictor of mortality in rural elderly people. Asian J Gerontol Geriatr 2019; 14(1): 15-22.

[http://dx.doi.org/10.12809/ajgg-2018-315-oa]

[34] Cladius S, Jadhav U, Ghewade B, Ali S, Dhamgaye T. Study of diabetes mellitus in association with tuberculosis. Journal of DattaMeghe Institute of Medical Sciences University 2017; 12(2): 143-7. 
[http://dx.doi.org/10.4103/jdmimsu.jdmimsu_62_17]

[35] 1Lancet Respir Med 2020; 2600(20): 30152-1. www.thelancet.com/ respiratory

[http://dx.doi.org/10.1016/S2213]

[36] Shahid Z, Kalayanamitra R, McClafferty B, et al. COVID-19 and older adults: What we know. J Am Geriat Soci 2020; 68(5): 926-9. [http://dx.doi.org/10.1111/jgs.16472]

[37] Vincent MJ, Bergeron E, Benjannet S, et al. Chloroquine is a potent inhibitor of SARS coronavirus infection and spread. Virol J 2005; 2 : 69.

[http://dx.doi.org/10.1186/1743-422X-2-69] [PMID: 16115318]

[38] Wang M, Cao R, Zhang L, et al. Remdesivir and chloroquine effectively inhibit the recently emerged novel coronavirus (2019-
$\mathrm{nCoV})$ in vitro Cell Res 2020; 30(3): 269-71.

[http://dx.doi.org/10.1038/s41422-020-0282-0] [PMID: 32020029]

[39] Update: Public Health Response to the Coronavirus Disease 2019 Outbreak - United States, February 24 2020. https://www. cdc.gov/mmwr/volumes/69/wr/mm6908e1.htm.Accessed

[40] Ogimi C, Englund JA, Bradford MC, Qin X, Boeckh M, Waghmare A Characteristics and outcomes of coronavirus infection in children: The role of viral factors and an immunocompromised state. J Pediatric Infect Dis Soc 2019; 8(1): 21-8

[http://dx.doi.org/10.1093/jpids/pix093] [PMID: 29447395]

[41] Cruz AT, Zeichner SL. COVID-19 in children: Initial characterization of the pediatric disease. In: Pediatrics. 2020; 145.(6) [http://dx.doi.org/10.1542/peds.2020-0834]

\section{(C) 2021 Reche et al.}

This is an open access article distributed under the terms of the Creative Commons Attribution 4.0 International Public License (CC-BY 4.0), a copy of which is available at: https://creativecommons.org/licenses/by/4.0/legalcode. This license permits unrestricted use, distribution, and reproduction in any medium, provided the original author and source are credited. 